\title{
Diffusive Transport of Phenolic Compounds Through Two Coextruded Geomembranes
}

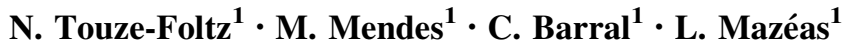

Received: 17 June 2015/Accepted: 17 July 2015 / Published online: 24 July 2015

(c) Springer International Publishing AG 2015

\begin{abstract}
This paper presents experimental results of a study of the diffusion of phenolic compounds through two High density polyethylene geomembranes (1 and $1.5 \mathrm{~mm}$ thick) with a coextruded ethylene vinyl-alcohol $(\mathrm{EVOH})$ inner core. The partition and diffusion coefficients were quantified for 2,4,6-tricholophenol (2,4,6-TCP), 2,3,5,6-tetrachlorophenol (2,3,5,6 TeCP), and pentachlorophenol, which are known to be toxic even at very low concentrations. The concentration dynamics in the source and receptor chambers of the diffusion cells was interpreted with the help of the numerical code POLLUTE. For partition coefficients greater than those obtained under the same conditions for a high-density polyethylene (HDPE) geomembrane, the diffusion coefficients are smaller than those for the same HDPE geomembrane. As a result, the permeation coefficient of the two coextruded geomembranes is the same order of magnitude as that of a 2-mm-thick HDPE geomembrane. Therefore, in contrast to the case for volatile organic compounds, the EVOH inner core brings no significant improvement. These results are compared to those previously obtained with volatile organic compounds for HDPE geomembranes and coextruded geomembranes.
\end{abstract}

Keywords Geosynthetics - Diffusion · Phenolic compounds $\cdot \mathrm{EVOH}$

N. Touze-Foltz

nathalie.touze@irstea.fr

1 Irstea - National Research Institute of Science and Technology, Paris, France

\section{Introduction}

Landfills contain micropollutants that can have toxic effects on the environment (acute toxicity, genotoxicity, reproductive toxicity, etc.) [1, 2]. In several countries, the presence of organic contaminants in the leachate from municipal solid-waste landfills has been clearly established [3-6]. The most-frequently encountered organic micropollutants in leachate are monoaromatic hydrocarbons (benzene, toluene, ethylbenzene, xylene) and polyaromatic (naphthalene, phenanthrene, etc.). In addition, some chlorinated solvents (trichlorethylene, chloromethane, etc.), plasticizers (phthalates, bisphenol A, etc.), pesticides, and phenolic derivatives are also found in leachate [7-15]. Phenolic compounds, especially certain derivatives of halogenated phenolic compounds, are known to be toxic to humans and the environment, even at very low concentrations. These compounds are used as disinfectants, biocides, preservatives, dyes, pesticides, and organic chemicals in medicine and industry [16-18].

To minimize the dispersal of such contaminants, geomembranes are widely used in geoenvironmental applications as barriers to water and contaminants. A number of studies regarding the use of geomembranes focused on the diffusion of sodium chloride [19] or volatile organic compounds (VOCs) in virgin high-density polyethylene (HDPE) geomembranes [20-24], virgin polyvinyl chloride (PVC) [25], linear low-density polyethylene (LLDPE) [25], LLDPE with a co-extruded ethylene vinylalcohol (EVOH) inner core [25-27], fluorinated HDPE geomembranes [28], and aged HDPE geomembranes [2931].

Results obtained by McWaters and Rowe [25] indicate a significant reduction in mass flux through coextruded geomembranes compared with conventional LLDPE. 
Coextruded geomembranes with an EVOH inner core have the lowest permeation coefficient, about $8 \times 10^{-15} \mathrm{~m}^{2} / \mathrm{s}$ for diffusion from the aqueous phase. These values for coextruded geomembranes are upper bounds; the actual values may be even less. The partition coefficients for the coextruded geomembrane range from 160 to 700 with respect to aqueous-phase concentrations. The resulting permeation coefficients thus range from $2 \times 10^{-12}$ to $6 \times 10^{-12} \mathrm{~m}^{2} / \mathrm{s}$ for the coextruded geomembrane. Thus, a coextruded geomembrane offers a five- to 12 -fold decrease in the permeation coefficient compared with a $2.0-\mathrm{mm}$ thick HDPE geomembrane [25].

Diffusion of phenolic compounds in HDPE geomembranes and HDPE films has also been the subject of recent study $[32,33]$. Similar measurements were recently done on other types of geomembranes, including two geomembranes with a coextruded EVOH inner core. This paper reports and discusses the results obtained for diffusion of phenolic compounds through such geomembranes in order to assess their ability to retain other micro-organic pollutants than VOCs in landfills.

\section{Materials and Methods}

\section{Geomembranes}

The diffusive transport of phenolic compounds was examined in two co-extruded geomembranes with a 0.05 mm-thick layer of EVOH. Both geomembranes had HDPE outer layers and were 1.0 and $1.5 \mathrm{~mm}$ thick. Their rate of cristallinity was measured to be $50 \%$. With its polar oxygen-hydrogen $(\mathrm{OH})$ groups, EVOH has outstanding barrier properties against nonpolar gases such as oxygen, nitrogen, volatile compounds, and helium [34]. EVOH laminar typically combines a highly ordered crystalline structure interspersed with disordered amorphous regions with high resistance against diffusion of gas and solvents $[25,34]$. However, to the best of our knowledge, the diffusion of phenolic compounds in $\mathrm{EVOH}$ has not yet been studied.

\section{Phenolic Compounds Under Study}

This work investigates the adsorption of 13 phenolic compounds: phenol, o-cresol (2-MP), p-cresol (4-MP), 2-chlorophenol (2-CP), 4-chlorophenol (4-CP), 2,4-xylenol (2,4-DMP), 3,4-xylenol (3,4-DMP), 2,4-dichlorophenol (2,4-DCP), 2,4,6-trichlorophenol (2,4,6-TCP), 2,3,5,6-tetrachlorophenol (2,3,5,6-TeCP), 2,3,4,6-tetrachlorophenol (2,3,4,6-TeCP), pentachlorophenol (PCP), and bisphenol A (BPA). Some of the physical and chemical properties of the selected phenolic compounds are given in Table 1.
All phenolic compounds studied except 2-chlorophenol are in the solid state at the laboratory temperature $\left(23{ }^{\circ} \mathrm{C}\right)$, with their melting points between 33 and $191{ }^{\circ} \mathrm{C}$. In general, these compounds dissolve poorly in water but well in organic solvents. Although the phenolic compounds with a high degree of chlorination $(\mathrm{pKa}=4.74)$ are classified as acids, some of them have a high $\mathrm{pKa}$. For example, phenol, methylphenol, and bisphenol $\mathrm{A}$ have $\mathrm{pKa} \sim 10$. For chlorophenols, the dissociation constant of the chlorinecontaining compound increases (i.e., $\mathrm{pKa}=-\log \mathrm{Ka}$ decreases) with increasing number of chlorine atoms in a molecule, from 2.29 for 2-chlorophenol to 5.85 for pentachlorophenol.

The octanol-water partitioning coefficient $K_{\text {ow }}$ of the pollutants concerned by this work increases strongly with the number of chlorine atoms, whereas the water solubility (hydrophilicity) decreases. The degree of dissociation of chlorophenols increases (indicated by decreasing $\mathrm{pKa}$ ) with increasing number of chlorine atoms. The properties of the various phenolic compounds are therefore expected to lead to different diffusion behavior in the geomembranes investigated in this study.

The phenolic compounds were chosen based on the following criteria: (1) polarity, (2) solubility in water, (3) mobility of pollutants in soils, (4) presence in leachate, and (5) toxicity. Concentrations were chosen based on two considerations: (1) a literature review to determine the minimum, maximum, and average concentrations of the phenolic compounds in leachate (see Table 2) [35-56], and (2) the limit of detection (LOD) and limit of quantification (LOQ) calculated according to the method developed by Limam et al. [57] to analyze these compounds via headspace solid-phase microextraction (HS-SPME) coupled with gas-chromatography mass spectrometry (GC-MS). The concentrations chosen for the chlorophenols and methylphenols are slightly greater than the average values found in leachate because the values encountered in the literature are significantly less than the LOQ.

The partition and diffusion coefficients could only be determined for 2,4,6-TCP, 2,3,4,6-TeCP, and PCP. For the other compounds, either the absorption was comparable to the diffusion in the source chamber (this was the case for the methylphenols) or the results tended to be suspect because inconsistent concentrations were obtained, both in the source and receptor chambers of the diffusion cell.

\section{Experimental Procedure}

\section{Preparation of Solutions}

Prior to the experiment, a stock solution of the 13 phenolic compounds dissolved in methanol was prepared at a 
Table 1 Physical and chemical properties of phenolic compounds under study

\begin{tabular}{|c|c|c|c|c|c|}
\hline Pollutants & Formula & Molecular weight (g/mol) & Solubility at $20^{\circ} \mathrm{C}(\mathrm{g} / \mathrm{L})$ & $\mathrm{p} K \mathrm{a}$ at $25^{\circ} \mathrm{C}$ & $\log \mathrm{K}_{\mathrm{ow}}$ \\
\hline Phenol & $\mathrm{C}_{6} \mathrm{H}_{6} \mathrm{O}$ & 94.04 & 90 & 9.95 & 1.46 \\
\hline \multicolumn{6}{|l|}{ Methylphenols } \\
\hline 2-MP & $\mathrm{C}_{7} \mathrm{H}_{8} \mathrm{O}$ & 108.14 & 26 & 10.20 & 1.96 \\
\hline 4-MP & $\mathrm{C}_{7} \mathrm{H}_{8} \mathrm{O}$ & 108.14 & 24 & 10.26 & 1.94 \\
\hline 3,4-DMP & $\mathrm{C}_{8} \mathrm{H}_{10} \mathrm{O}$ & 122.17 & - & 10.3 & 2.23 \\
\hline 2,4-DMP & $\mathrm{C}_{8} \mathrm{H}_{10} \mathrm{O}$ & 122.17 & 5 & 10.6 & 2.30 \\
\hline \multicolumn{6}{|l|}{ Chlorophenols } \\
\hline $2-\mathrm{CP}$ & $\mathrm{C}_{6} \mathrm{H}_{5} \mathrm{ClO}$ & 128.56 & 28 & 8.52 & 2.29 \\
\hline $4-\mathrm{CP}$ & $\mathrm{C}_{6} \mathrm{H}_{5} \mathrm{ClO}$ & 128.56 & 27 & 9.37 & 2.53 \\
\hline 2,4-DCP & $\mathrm{C}_{6} \mathrm{H}_{4} \mathrm{Cl}_{2} \mathrm{O}$ & 163.00 & 4.5 & 7.90 & 3.20 \\
\hline $2,4,6-\mathrm{TCP}$ & $\mathrm{C}_{6} \mathrm{H}_{3} \mathrm{Cl}_{3} \mathrm{O}$ & 197.45 & 0.434 & 6.00 & 3.67 \\
\hline 2,3,4,6-ТeCP & $\mathrm{C}_{6} \mathrm{H}_{2} \mathrm{Cl}_{4} \mathrm{O}$ & 231.89 & 0.183 & 5.22 & 4.24 \\
\hline 2,3,5,6-ТeCP & $\mathrm{C}_{6} \mathrm{H}_{2} \mathrm{Cl}_{4} \mathrm{O}$ & 231.89 & 0.100 & 5.02 & 5.02 \\
\hline PCP & $\mathrm{C}_{6} \mathrm{Cl}_{5} \mathrm{OH}$ & 266.34 & 0.014 & 4.74 & 5.85 \\
\hline BPA & $\mathrm{C}_{15} \mathrm{H}_{16} \mathrm{O}_{2}$ & 228.29 & 0.3 & $9.59-11.30$ & 3.40 \\
\hline
\end{tabular}

Table 2 Concentrations chosen for experiments from minimum and maximum values of concentrations measured in leachate

\begin{tabular}{|c|c|c|c|c|c|c|}
\hline Contaminants & Min. value $(\mu \mathrm{g} / \mathrm{L})$ & Max. value $(\mu \mathrm{g} / \mathrm{L})$ & Mean value $(\mu \mathrm{g} / \mathrm{L})$ & Corrected mean $(\mu \mathrm{g} / \mathrm{L})$ & LOD (ng/L) & $c(\mu \mathrm{g} / \mathrm{L})$ \\
\hline Phenol & 0.030 & 1200.000 & 127.198 & 46.99 & 345.67 & 100 \\
\hline \multicolumn{7}{|l|}{ Methylphenols } \\
\hline 2-MP & 0.070 & 185.000 & 71.607 & 71.60 & 43.76 & 100 \\
\hline 4-MP & 6.000 & $12,000.000$ & 4493.200 & 588.00 & 14.51 & 100 \\
\hline 3,4-DMP & 0.030 & 10.400 & 3.423 & 3.42 & - & 10 \\
\hline 2,4-DMP & 0.120 & 13.000 & 4.504 & 4.50 & 18.88 & 10 \\
\hline \multicolumn{7}{|l|}{ Chlorophenols } \\
\hline $2-\mathrm{CP}$ & 0.003 & 0.510 & 0.107 & 0.06 & 16.47 & 10 \\
\hline $4-\mathrm{CP}$ & 0.070 & 1.300 & 0.611 & 0.61 & - & 10 \\
\hline 2,4-DCP & 0.010 & 12.820 & 1.026 & 0.30 & 1.04 & 10 \\
\hline $2,4,6-\mathrm{TCP}$ & 0.002 & 1.870 & 0.162 & 0.06 & 1.11 & 10 \\
\hline 2,3,4,6-ТеCP & 0.032 & 20.400 & 2.709 & 0.18 & 1.54 & 10 \\
\hline 2,3,5,6-ТeCP & 0.012 & 0.012 & 0.012 & 0.01 & 1.15 & 10 \\
\hline PCP & 0.015 & 21.610 & 3.798 & 0.83 & 1.07 & 10 \\
\hline BPA & 0.350 & $25,000.000$ & 3565.900 & 784.50 & 1.37 & 1000 \\
\hline
\end{tabular}

concentration 1000 times greater than the concentration of the solution used for the diffusion experiments (see Table 2). In a volumetric flask, $0.001 \mathrm{~g}$ of each chlorophenol was mixed with methanol to obtain $100 \mathrm{~mL}$ of the stock solution, which was then stored at $-20{ }^{\circ} \mathrm{C}$. To obtain the desired concentration for the diffusion experiments the stock solution was diluted with deionized distilled water (DDW). The resulting solution was used both as the source in the diffusion cells and for preparing standards with which to calibrate the gas chromatograph. The internal standard solution was prepared with 2,4,6-tricholorophenol $13 \mathrm{C} 6$ and pentachlorophenol 13C6, which are compounds containing isotopes of carbon 13 (13C6).

\section{Batch-Partitioning Experiments}

\section{Experimental Procedure}

Batch-partitioning experiments were performed at room temperature $\left(23 \pm 1{ }^{\circ} \mathrm{C}\right)$ in $200 \mathrm{~mL}$ glass bottles equipped 
with screw-on Teflon-lined caps for sampling. The experimental procedure was based on that of Islam and Rowe [31]. The geomembranes were cut into pieces for the batchpartitioning experiments. According to Nefso and Burns [58], cutting the geomembrane into smaller pieces does not affect the ultimate sorption capacity because the equilibrium between organic-pollutant and polymer sorption is a dissolution-controlled process, not a surface-controlled process.

Four bottles were used. Bottles I1 and I 2 contained $6 \mathrm{~g}$ of geomembrane cut into pieces and immersed in $120 \mathrm{~mL}$ of diffusion solution. Following Touze-Foltz et al. [32] and Mendes et al. [33], the solid/liquid ratio was $1 / 20$. The other two bottles, $\mathrm{C} 1$ and $\mathrm{C} 2$, were used for control experiments and contained only a solution identical to that used in the diffusion tests (i.e., no geomembrane). A biocide agent $\left(400 \mathrm{mg} / \mathrm{L} \mathrm{HgCl}_{2}\right)$ was added to all four bottles to limit the effects of biodegradation, as recommended by Touze-Foltz et al. [32] and Mendes et al. [33]. To calculate the partition coefficient $S_{\mathrm{gf}}$, the concentrations of the various chlorophenols were measured at the beginning $\left(t_{0}\right)$ and at the end $\left(t_{\mathrm{f}}\right)$ of the diffusion experiments. To make the experiment repeatable, two samplings were taken from each of the four bottles at each specific sampling date.

\section{Calculation of Partition Coefficient}

The concentration of contaminant in the geomembranes, $c_{\mathrm{g}}$, and in solution, $c_{\mathrm{f}}$, are linked by Henry's Law [23]:

$c_{\mathrm{g}}=S_{\mathrm{gf}} c_{\mathrm{f}}$,

where $S_{\mathrm{gf}}$ is the partition coefficient, which depends on temperature, fluid, geomembrane, and contaminant. The partition coefficients $S_{\mathrm{gf}}$ were calculated for each bottle and each phenolic compound by using the following equation adapted from Sangam and Rowe [23]:

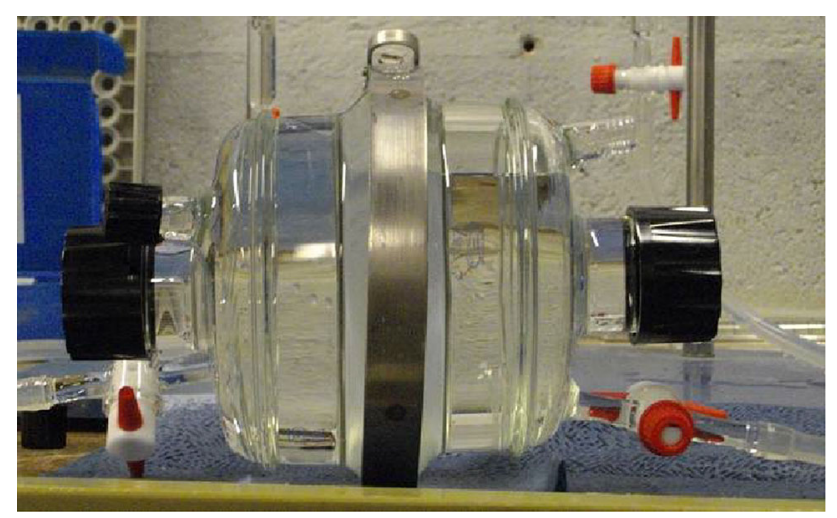

Fig. 1 Diffusion cell with two identical parts separated by the geomembrane and linked with metallic bridle. This cell is identical to the control test cell
$S_{\mathrm{gf}}=\frac{\left[\left(c_{\mathrm{f} 0} V_{\mathrm{f} 0}\right)\left(1-p_{\mathrm{s}}\right)-c_{\mathrm{fF}} V_{\mathrm{fF}}-\Sigma c_{\mathrm{i}} V_{\mathrm{i}}\right] \rho_{\mathrm{g}}}{M_{\mathrm{g}} c_{\mathrm{fF}}}$,

where $c_{\mathrm{fo}}$ and $c_{\mathrm{fF}}$ are the initial and final concentrations of the solution in $\mathrm{g} / \mathrm{L}$, respectively, $V_{\mathrm{fo}}$ and $V_{\mathrm{fF}}$ are the initial and final volumes of the solution in $\mathrm{L}$, respectively, $p_{\mathrm{s}}$ is the proportion of contaminant sorbed onto the glass as determined from the evolution of the concentration in bottles $C_{1}$ and $C_{2}$ and which is assumed to be independent of whether a geomembrane is present, $\rho_{\mathrm{g}}$ is the density in $\mathrm{g} / \mathrm{L}$ of the geomembrane, and $M_{g}$ is the initial mass in $\mathrm{g}$ of the geomembrane in bottles $I_{1}$ and $I_{2}$ (Fig. 1).

\section{Diffusion Experiment}

\section{Apparatus}

The apparatus, shown in Fig. 2, consists of two independent cylindrical glass chambers identical to the diffusionexperiment apparatus previously used by Touze-Foltz et al. $[32,59]$ to quantify the diffusion in HDPE geomembranes. Diffusion-experiment apparatus have an internal diameter of $0.12 \mathrm{~m}$ and the volume of each chamber is $0.73 \mathrm{~L}$.

Each geomembrane specimen was placed between the two chambers of the diffusion-experiment apparatus, and the two chambers were then assembled with the help of a metal screw clamp. No sealant or O-ring was used. Each geomembrane was in direct contact with the glass cell on both sides. Each chamber contained a sampling port with a Teflon cap and a second port that could be used to fill the cell.

To assess the mass loss due to sorption onto the glass cell, the same diffusion apparatus was used as a control cell in blank experiments (i.e., with no geomembrane). Blank experiments were performed in parallel to the diffusion experiments. None of the samples were stirred.

\section{Experimental Procedure}

The experimental procedure is as follows: (i) The receptor chamber of the diffusion cell is filled with DDW, (ii) the source chamber of the diffusion cell is filled with the previously prepared diffusion solution containing chlorophenols, (iii) in both chambers, $400 \mathrm{mg} / \mathrm{L}$ of a biocide agent $\left(\mathrm{HgCl}_{2}\right)$ is added to minimize biodegradation of the phenolic compounds, and (iv) the cells are covered with aluminum sheets to avoid photodegradation of the phenolic compounds. The experimental configuration ensured that there was no hydraulic gradient. The experiments were performed at $23 \pm 1{ }^{\circ} \mathrm{C}$ in glass cells.

The solutions were immediately sampled (in duplicate) to establish the initial concentrations of each phenolic compound in the source and receptor chambers. Subsequent 
Fig. 2 Relative concentration as a function of time in blank diffusion experiment

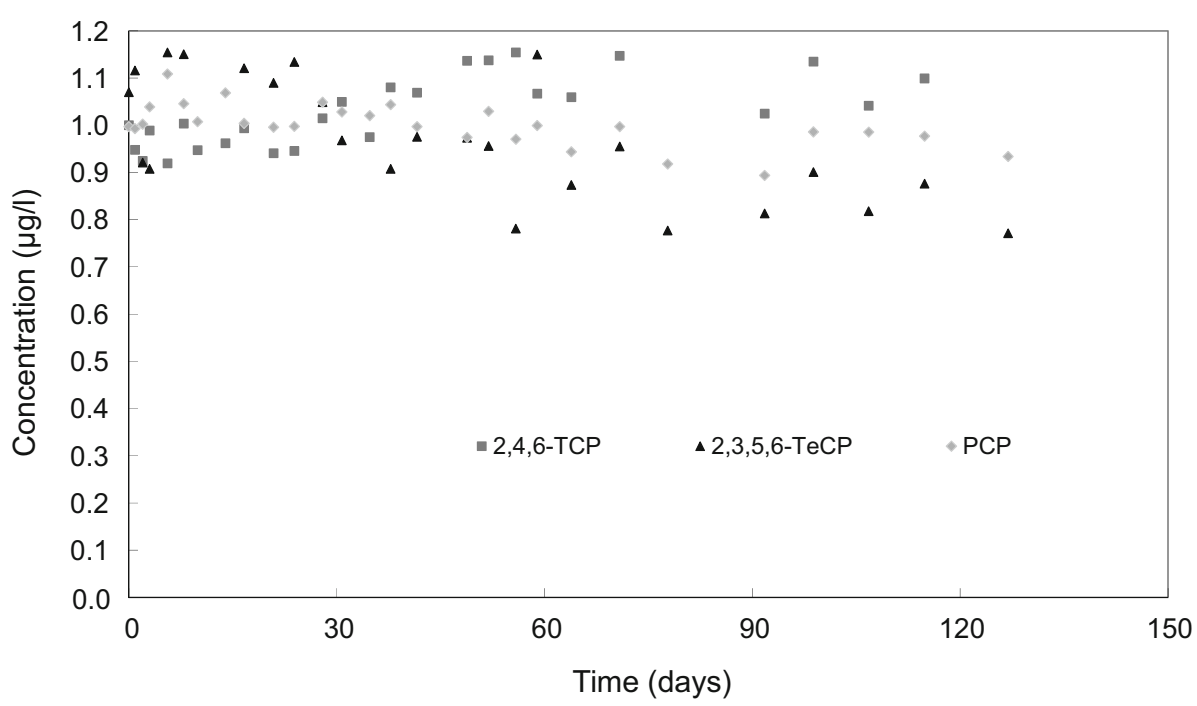

samplings were performed at regular time intervals (in duplicate) from both the source and receptor chambers. Samples were taken by inserting a syringe through the Teflon-lined septum of the sampling ports.

\section{Calculation of Diffusion Coefficient}

The diffusion of organic compounds through geomembranes can be modeled by Fick's first law [23]:

$f=-D_{\mathrm{g}} \frac{\mathrm{d} c_{g}}{\mathrm{~d} z}$,

where $f$ is the mass flux or permeation rate per unit area $(\mathrm{g} /$ $\left.\mathrm{m}^{2} / \mathrm{s}\right), D_{\mathrm{g}}$ is the diffusion coefficient of organic compounds $\left(\mathrm{m}^{2} / \mathrm{s}\right), c_{\mathrm{g}}$ is the concentration of the compound in the geomembrane $(\mathrm{g} / \mathrm{L})$, and $z$ is the distance parallel to the direction of diffusion (m).

According to Fick's second law, the change with time $t$ in contaminant concentration at any point in the geomembrane is governed by the differential equation [23]:

$\frac{\partial c_{g}}{\partial t}=D_{\mathrm{g}} \frac{\partial^{2} c_{g}}{\partial z^{2}}$.

The experimental procedure was based on concepts and theory proposed for geomembranes by Rowe et al. [29], Sangam and Rowe [23], and Islam and Rowe [31]. For these closed systems, the mass of contaminant in the source solution at any time $t$ equals the initial mass minus the mass that diffused through the geomembrane. This can be expressed as

$c_{\mathrm{t}}(t)=c_{0}-\frac{1}{H_{\mathrm{s}}} \int_{0}^{1} f_{\mathrm{t}}(\tau) \mathrm{d} \tau$, where $c_{\mathrm{t}}(t)$ is the concentration in $\mathrm{g} / \mathrm{L}$ of contaminants in the source solution at time $t, c_{0}$ is the initial concentration in $\mathrm{g} / \mathrm{L}$ in the source solution, $H_{\mathrm{s}}$ is the height in meters of the source fluid (volume of source fluid per unit area), and $f_{\mathrm{t}}(\tau)$ is the mass flux in $\mathrm{g} / \mathrm{m}^{2} / \mathrm{s}$ of contaminant into the geomembrane at time $\tau$. The concentration $c_{\mathrm{b}}(t)$ in the receptor compartment at any time can be expressed as

$c_{\mathrm{b}}(t)=c_{\mathrm{b} 0}-\frac{1}{H_{\mathrm{b}}} \int_{0}^{1} f_{\mathrm{b}}(\tau) \mathrm{d} \tau$,

where $c_{\mathrm{b} 0}(t)$ is the initial concentration in $\mathrm{g} / \mathrm{L}$ in the receptor solution, $H_{\mathrm{b}}$ is the height in meters of the receptor (volume of receptor chamber per unit area), and $f_{\mathrm{b}}(\tau)$ is the mass flux in $\mathrm{g} / \mathrm{m} / \mathrm{s}$ of contaminant into the receptor chamber at time $\tau$.

The diffusion coefficient $D_{\mathrm{g}}$ and partition coefficient $S_{\mathrm{gf}}$ were deduced by using the procedure described by Sangam and Rowe [23] and the finite-layer analysis program POLLUTE ver. 7@ [60].

The permeation coefficient is obtained as the product of the diffusion coefficient by the partition coefficient.

\section{Analytical Methods}

The concentration of each phenolic compound in solution was measured by HS-SPME-GC-MS following the analytical method developed by Limam et al. [57]. The GCMS (trace GC and DSQ, dual-stage quadrupole, Thermo Fischer) was equipped with a Combi PAL autosampler (CTC Analytics) to enable automatic SPME extraction. The GC split-splitless injector was operated in splitless mode. The chromatographic column was a Zebron 5 MS column 
(5\% phenyl-methylpolysiloxane, Phenomenex, $60 \mathrm{~m}$ length, $0.25 \mathrm{~mm}$ inner diameter, $0.25 \mu \mathrm{m}$ film thickness). Chromatographic separation was done by using the following eight temperature stages: (1) $40{ }^{\circ} \mathrm{C}$ for $5 \mathrm{~min}$; (2) an increase to $115^{\circ} \mathrm{C}$ at $15^{\circ} \mathrm{C} / \mathrm{min}$; (3) an increase to $175^{\circ} \mathrm{C}$ at $3{ }^{\circ} \mathrm{C} / \mathrm{min}$; (4) $175^{\circ} \mathrm{C}$ for $5 \mathrm{~min}$; (5) an increase to $250{ }^{\circ} \mathrm{C}$ at $30{ }^{\circ} \mathrm{C} / \mathrm{min}$; (6) $250{ }^{\circ} \mathrm{C}$ for $2 \mathrm{~min}$; (7) an increase to $280{ }^{\circ} \mathrm{C}$ at $30{ }^{\circ} \mathrm{C} / \mathrm{min}$, and (8) $280{ }^{\circ} \mathrm{C}$ for $5 \mathrm{~min}$. The injector temperature was held at $250{ }^{\circ} \mathrm{C}$ and the splitless time was 5 min. Helium served as carrier gas with a column flow rate of $1.1 \mathrm{~mL} / \mathrm{min}$. The Xcalibur software from Thermo Fisher was used for online data acquisition and processing. The fiber consisted of a $100 \mu \mathrm{m}$ polydimethylsiloxane (PDMS) from Supelco. Two internal standards were used for quantification: (a) 4,6-trichlorophenol-13C for 2,4,6-TCP and (b) pentachlorophenol-13C6 for 2,3,5,6-TeCP and PCP.

The quantification procedure involved two steps: derivatization and headspace extraction. The derivatization step consists of adding $2 \mathrm{~g}$ of sodium chloride $(\mathrm{NaCl} ; 40 \%$ $\mathrm{W} / \mathrm{V}), 200 \mathrm{mg}$ of potassium bicarbonate $\left(\mathrm{KHCO}_{3}\right)$, and $30 \mu \mathrm{L}$ of anhydride acetic acid $\left[\left(\mathrm{CH}_{3} \mathrm{CO}\right)_{2} \mathrm{O}\right]$ into a $20 \mathrm{~mL}$ PTFE-capped glass vial containing $5 \mathrm{~mL}$ of aqueous sample. The sodium chloride saturates the solution, which permits the phenolic compounds to pass easily into the gas phase, thereby improving the sensitivity of the measurement. The sodium bicarbonate $\left(\mathrm{KHCO}_{3}\right)$ avoids degradation of the phenolic compounds that would otherwise result from the addition of anhydride acetic acid $\left[\left(\mathrm{CH}_{3} \mathrm{CO}\right)_{2} \mathrm{O}\right]$. The sequence in which these reagents are added is essential because introducing the anhydride acetic acid $\left[\left(\mathrm{CH}_{3} \mathrm{CO}\right)_{2}\right.$ $\mathrm{O}$ ] first could lead to underestimating the compound concentration. The derivation reaction is completed with a 5 min $80{ }^{\circ} \mathrm{C}$ pre-incubation period.

Pre-incubation was followed by extraction of the given chlorophenol compound by using the SPME fiber covered with a $100-\mu \mathrm{m}$-thick PDMS film at $80{ }^{\circ} \mathrm{C}$ for $30 \mathrm{~min}$ under agitation (500 rpm). Injection into the GC-MS was done at $250{ }^{\circ} \mathrm{C}$, lasted $5 \mathrm{~min}$, and led to desorption of phenolic compounds from the fiber in the injector. Phenolic compounds were quantified by using the single-ion monitoring mode (SIM). The ion mass-to-charge ratio $m / Z=196,232$, and 266 were used for 2,4,6-TCP; 2,3,5,6-TeCP; and PCP, respectively.

\section{Results}

\section{Control Cell}

To access the mass loss due to sorption onto the glass cell, a blank diffusion experiment was done by using the diffusion apparatus with no specimen. The experiment was done in parallel with the diffusion experiments. Figure 2 presents the temporal evolution of contaminant concentrations (normalized with respect to initial concentration) in blank diffusion experiments. The decrease in concentration due to sorption is negligible for the three chlorophenols.

\section{Partitioning Tests}

Following the methodology described in "Batch-Partitioning Experiments" section, the partition coefficients $S_{\mathrm{gf}}$ for each phenolic compound were calculated with the assumption that the mass loss onto glass would occur even in the presence of a geomembrane. The corresponding partition coefficients are given in Table 3 where, for the sake of comparison, the values obtained by Touze-Foltz et al. [32] for a HDPE geomembrane are also reported.

The only difference is the partition coefficients obtained for 2,4,6-TCP. This result is considered very reliable because it was obtained based on the measurement of four different batch tests for each geomembrane (two for lot A and two for lot B). For all three phenolic compounds, the partition coefficients obtained for the EVOH geomembranes are larger than those measured for a HDPE geomembrane.

\section{Diffusion Experiments}

Figure 3 shows the concentration dynamics of 2,4,6 TCP in the source chamber and the adjustment made with POLLUTE with diffusion coefficients of $5 \times 10^{-15}$ and $4 \times 10^{-14} \mathrm{~m}^{2} / \mathrm{s}$, respectively, for the 1 and $1.5-\mathrm{mm}$-thick geomembranes. With these diffusion coefficients and partition coefficients, negligible concentrations accumulate in the receptor chamber during the measurement. The results of the model are consistent with experimental results on this score.

Figure $4 \mathrm{a}$, b show the concentration dynamics of 2,3,5,6 $\mathrm{TeCP}$ in the source and receptor chambers, respectively. These curves were obtained for diffusion coefficients of $2 \times 10^{-14}$ and $3 \times 10^{-14} \mathrm{~m}^{2} / \mathrm{s}$ for the 1 and $1.5-\mathrm{mm}$-thick geomembranes, respectively.

Figure 5 shows the concentration dynamics of PCP in the source chamber and the adjustment obtained made with

Table 3 Inferred partition coefficients from measurements made for present study and from HDPE geomembranes according to TouzeFoltz et al. [32]

\begin{tabular}{lllc}
\hline Contaminants & $\mathrm{S}_{\mathrm{gf} 1 \mathrm{~mm}}(-)$ & $\mathrm{S}_{\mathrm{gf} 1.5 \mathrm{~mm}}(-)$ & $\mathrm{S}_{\mathrm{gf}}$ for HDPE (-) \\
\hline $2,4,6-\mathrm{TCP}$ & 265 & 103 & 18 \\
$2,3,5,6-\mathrm{TeCP}$ & 378 & 377 & 38 \\
PCP & 480 & 480 & 205 \\
\hline
\end{tabular}


Fig. 3 Concentration as a function of time in source of diffusion cell for 2,4,6-TCP for both geomembranes and with adjustment done with POLLUTE ver. 7

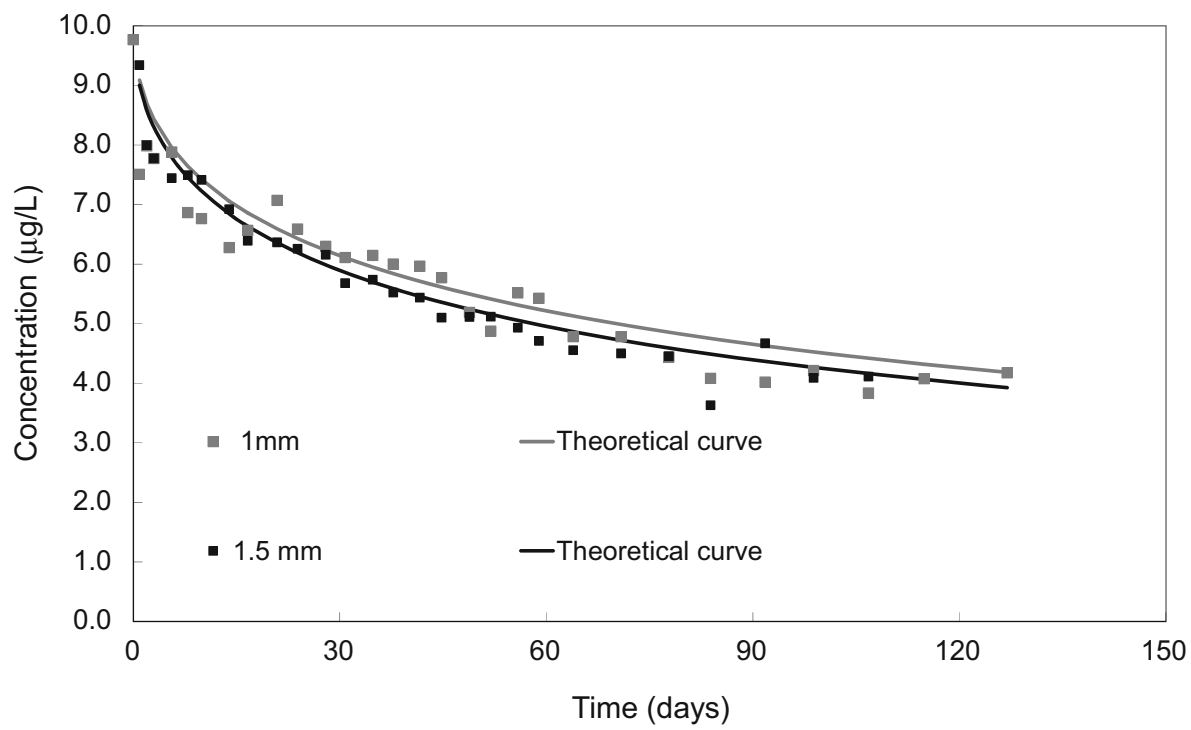

POLLUTE with a diffusion coefficient of $10^{-13} \mathrm{~m}^{2} / \mathrm{s}$ for both geomembranes.

Diffusion coefficients corresponding to the best-fit curve are given in Table 4, together with the permeation coefficient $P_{\mathrm{g}}$, which is the product of the partition coefficient and the diffusion coefficient. In the same table, these two coefficients are compared to previous results for the same coefficients obtained by Touze-Foltz et al. [32] for a HDPE geomembrane measured under similar conditions. The permeation coefficients are comparable for both types of geomembranes. Results obtained for both coextruded geomembranes and for the HDPE geomembrane are of the same order of magnitude.

\section{Discussion}

\section{Influence of Chlorine Atoms on Diffusion Parameters}

The results indicate that the partition coefficient is closely linked to the degree of substitution of chlorine atoms on the phenolic nucleus. Larger numbers of chlorine atoms correspond to larger partition coefficients. This phenomenon is most likely due to the difference in polarity of the chlorophenols, as previously noticed by Touze-Foltz et al. [32] and Mendes et al. [33] for HDPE films and geomembranes.

Diffusion coefficients generally increase with increasing number of chlorine atoms.

\section{Influence of $\boldsymbol{n}$-Octanol-Water Partition Coefficient}

Previous studies revealed that the $n$-octanol-water partition coefficient, $\log K_{\text {ow }}$, affects the molecular diameter $d_{\mathrm{m}}$, the solubility $S$, and the molecular weight and thereby affects the diffusion coefficient, partition coefficient, and permeation coefficient. As found in the present study, the diffusion coefficient is two orders of magnitude less than the diffusion coefficient for HDPE geomembranes, and the partition coefficient is two orders of magnitude greater than the partition coefficient for HDPE geomembranes. This combination results in a permeation coefficient that is the same order of magnitude because it is the product of the diffusion coefficient and the partition coefficient. The evolution of the permeation coefficient is shown in Fig. 6.

Figures 6 shows permeation coefficients for VOCs and phenolic compounds both from the literature and from this study. In Fig. 6a-d, the data displayed regarding the diffusion of VOCs in HDPE geomembranes originate from Park and Nibras [20], Prasad et al. [21], Müller et al. [22], Rowe [61], Sangam and Rowe [23], Rowe et al. [29], Joo et al. [62, 63], Nefso and Burns [58], Islam and Rowe [31], Touze-Foltz et al. [59], and Park et al. [24]. Data regarding the diffusion of VOCs in coextruded geomembranes originate from McWatters and Rowe [25] and Eun et al. [27]. The diffusion of phenolic compounds through a 2-mmthick HDPE geomembrane was quantified by Touze-Foltz et al. [32] and by Mendes et al. [33] for 0.3-mm-thick HDPE films. These data show that the permeation coefficient increases with increasing $\log K_{\text {ow }}$. 
Fig. 4 Concentration as a function of time $\mathbf{a}$ in source of diffusion cell and $\mathbf{b}$ in receptor of diffusion cell for 2,3,5,6$\mathrm{TeCP}$ and adjustment with POLLUTE ver. 7 for both geomembranes

\section{(a)}
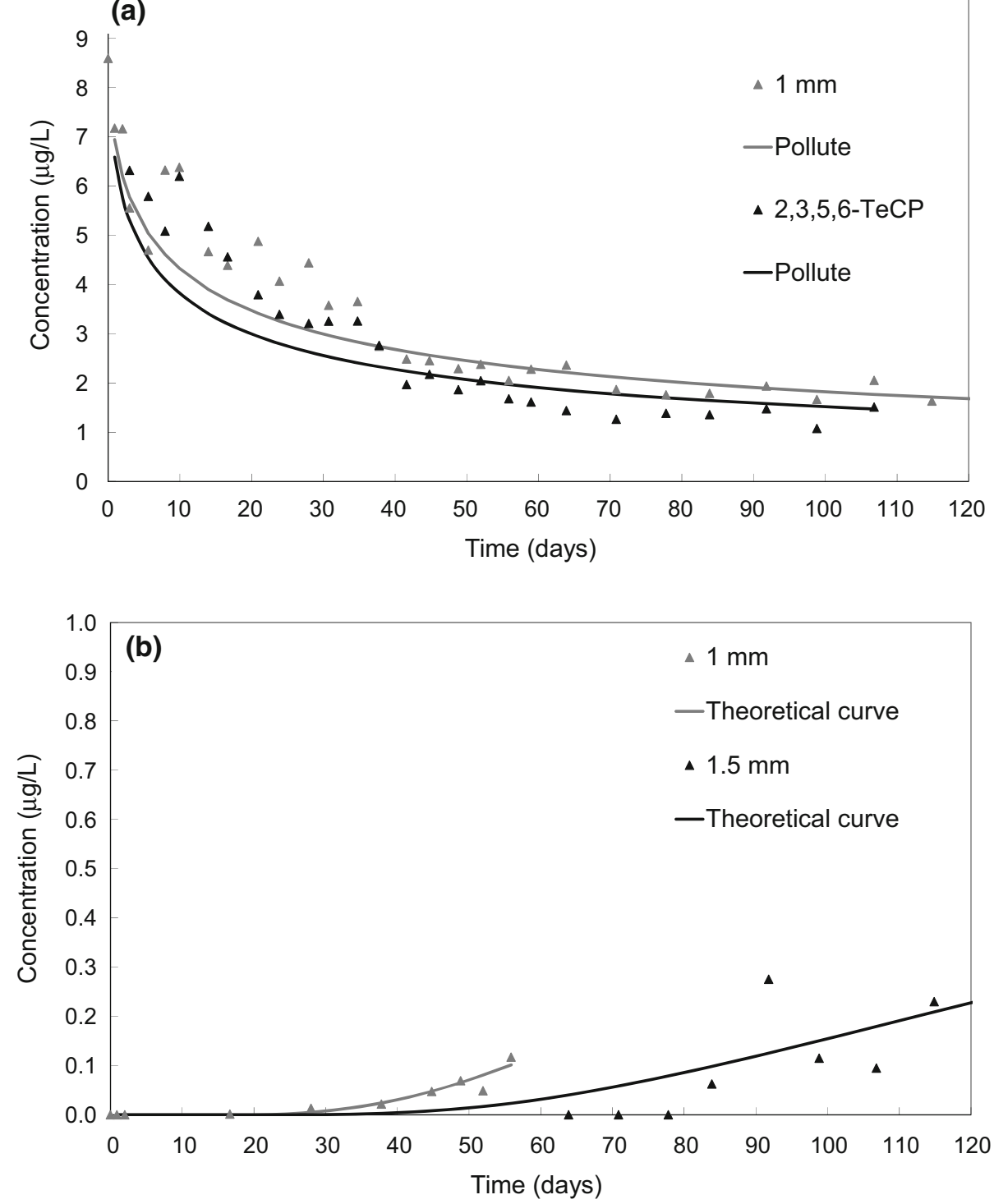

Two different trends appear in Fig. 6a: a first cloud of data points that corresponds to the diffusion of VOCs (squares) and a second cloud of data points that corresponds to data for the diffusion of phenolic compounds (triangles). These data show that the permeation coefficient is larger for VOCs than for phenolic compounds.

Note that, although the permeation coefficient for VOCs in coextruded geomembranes is less than that obtained in HDPE geomembranes, this is not the case for the diffusion of phenolic compounds. In fact, as previously noticed in Table 3 , for a given contaminant (which also means a given $\log K_{\mathrm{ow}}$ ), the permeation coefficient obtained for co-extruded geomembranes are similar to that obtained for HDPE geomembranes. The smallest permeation coefficients are obtained from the HDPE films measured by Mendes et al. [33].

\section{Influence of Solubility}

Figure $6 \mathrm{~b}$ shows the permeation coefficient as a function of solubility. The permeation coefficient decreases with increasing solubility. Again, two very distinct trends appear, with the cloud of data for the diffusion of VOCs being separate from the cloud of data for the diffusion of phenolic compounds, which is attributed to both families having different ranges of solubility. The decrease of the permeation coefficient with solubility is almost linear for phenolic compounds, whereas no clear trend appears for the permeation coefficient with VOCs. This result may be connected with the number of data, which is greater for phenolic compounds because they have been more studied up to now. 
Fig. $5 \mathrm{C}$ oncentration as a function of time in source of diffusion cell for PCP and adjustment with POLLUTE ver. 7 for both geomembranes

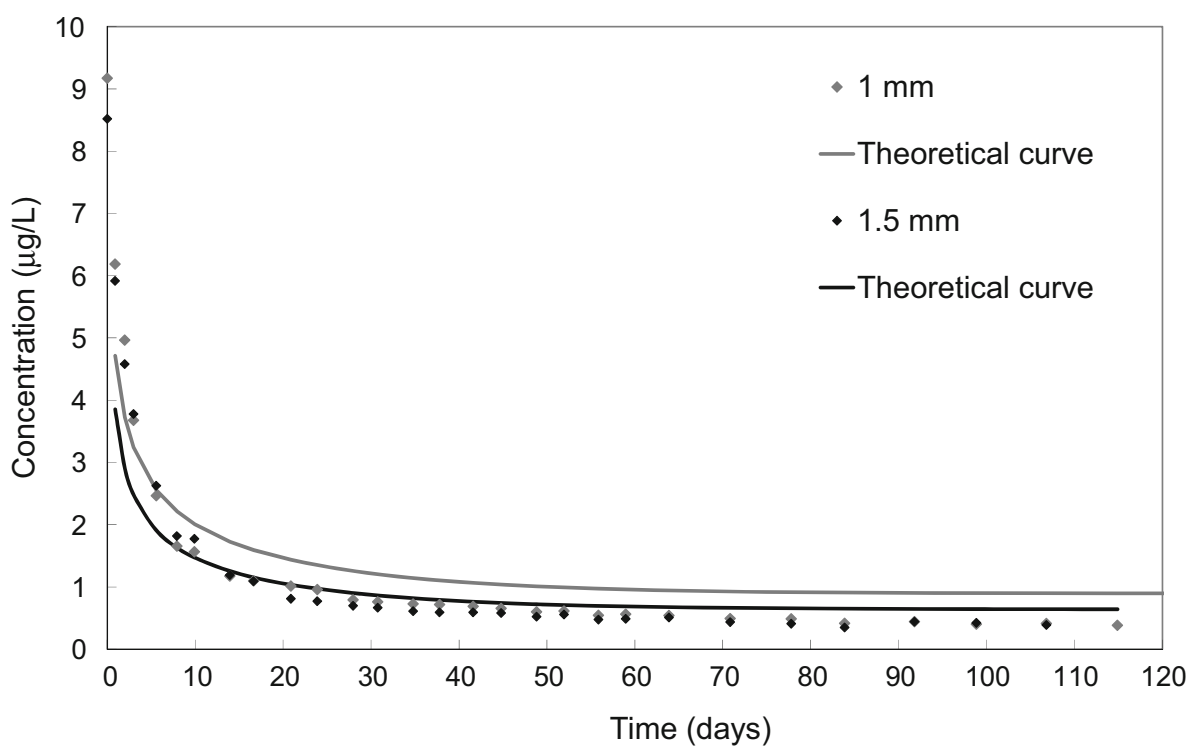

Table 4 Inferred diffusion and permeation coefficients from measurements made for present study and from a HDPE geomembrane according to Touze-Foltz et al. [32]

\begin{tabular}{|c|c|c|c|c|c|c|}
\hline \multirow[t]{2}{*}{ Contaminants } & \multicolumn{2}{|l|}{$1 \mathrm{~mm} \mathrm{GMB}$} & \multicolumn{2}{|l|}{$1.5 \mathrm{~mm} \mathrm{GMB}$} & \multicolumn{2}{|l|}{ HDPE GM } \\
\hline & $\operatorname{Dg}\left(\times 10^{-14} \mathrm{~m}^{2} / \mathrm{s}\right)$ & $\mathrm{Pg}\left(\times 10^{-14} \mathrm{~m}^{2} / \mathrm{s}\right)$ & $\begin{array}{l}\mathrm{Dg}\left(\times 10^{-14}\right. \\
\left.\mathrm{m}^{2} / \mathrm{s}\right)\end{array}$ & $\operatorname{Pg}\left(\times 10^{-14} \mathrm{~m}^{2} / \mathrm{s}\right)$ & $\operatorname{Dg}\left(\times 10^{-14} \mathrm{~m}^{2} / \mathrm{s}\right)$ & $\operatorname{Pg}\left(\times 10^{-14} \mathrm{~m}^{2} / \mathrm{s}\right)$ \\
\hline $2,4,6-\mathrm{TCP}$ & 0.5 & 132 & 4 & 412 & 15 & 270 \\
\hline 2,3,5,6-ТеCP & 2 & 756 & 3 & 1131 & 23 & 885 \\
\hline PCP & 10 & 4800 & 10 & 4800 & 18 & 3699 \\
\hline
\end{tabular}

\section{Influence of Molecular Diameter}

Figure $6 \mathrm{c}$ shows the partition coefficients as a function of molecular diameter. Again, the data for the diffusion of VOCs are distinct from those for phenolic compounds. No clear trend appears regarding the evolution of the permeation coefficient with molecular diameter. This parameter seems to be the less explicative of all.

\section{Influence of Molecular Weight}

Figure 6d shows the permeation coefficients as a function of molecular weight. The results show that the permeation coefficient increases with molecular weight. The range of molecular weights for phenolic compounds is larger than for VOCs, which results in a wider distribution of partition coefficients for the former.

The good correlation observed for phenolic compounds may be explained by the fact that differences in molecular weight are due to the number of chlorine atoms in a molecule: The more chlorine atoms in a molecule, more apolar it is. Thus, for chlorophenols, the good correlation between molecular weight and partition coefficient may be related to polarity.

\section{Conclusion}

The diffusion of three phenolic compounds, 2,4,6-TCP, 2,3,5,6-TeCP, and PCP was quantified for 1 and 1.5-mmthick coextruded geomembranes. The results for the partition coefficient and diffusion coefficient are very consistent for both geomembranes for 2,3,5,6-TeCP and PCP. For 2,4,6-TCP, the coefficients are slightly different for geomembranes of different thickness.

The partition coefficients are larger for the coextruded geomembranes than for HDPE geomembranes. This result is balanced by smaller diffusion coefficients for both coextruded geomembranes. This leads to permeation coefficients that are of the same order of magnitude for coextruded geomembranes and HDPE geomembranes. 


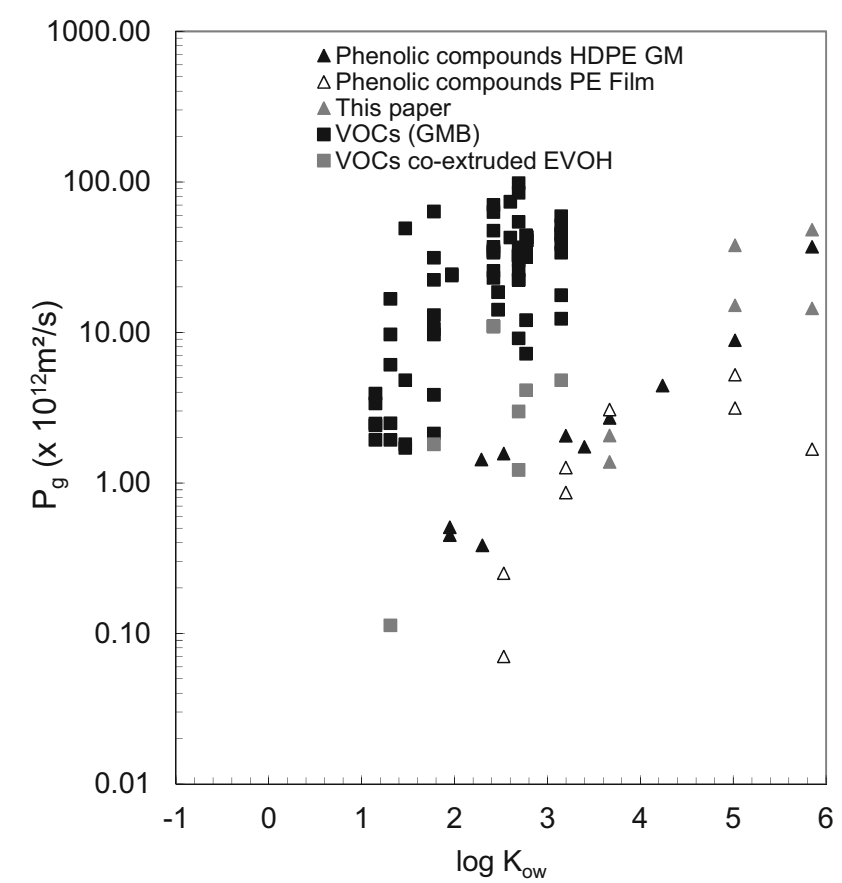

(a)

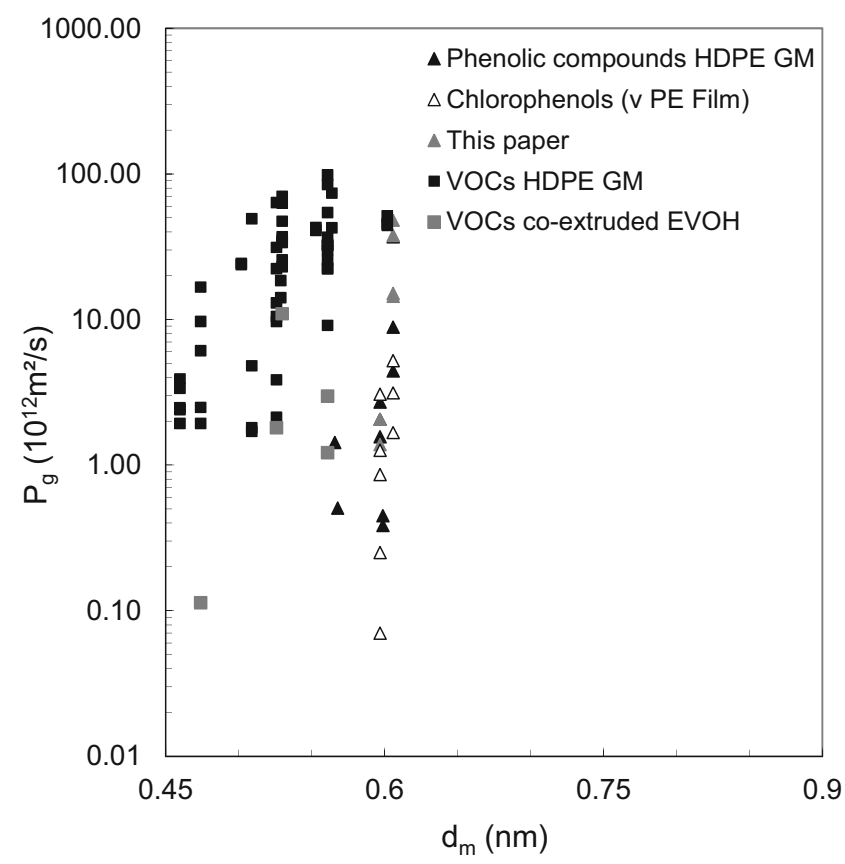

(c)

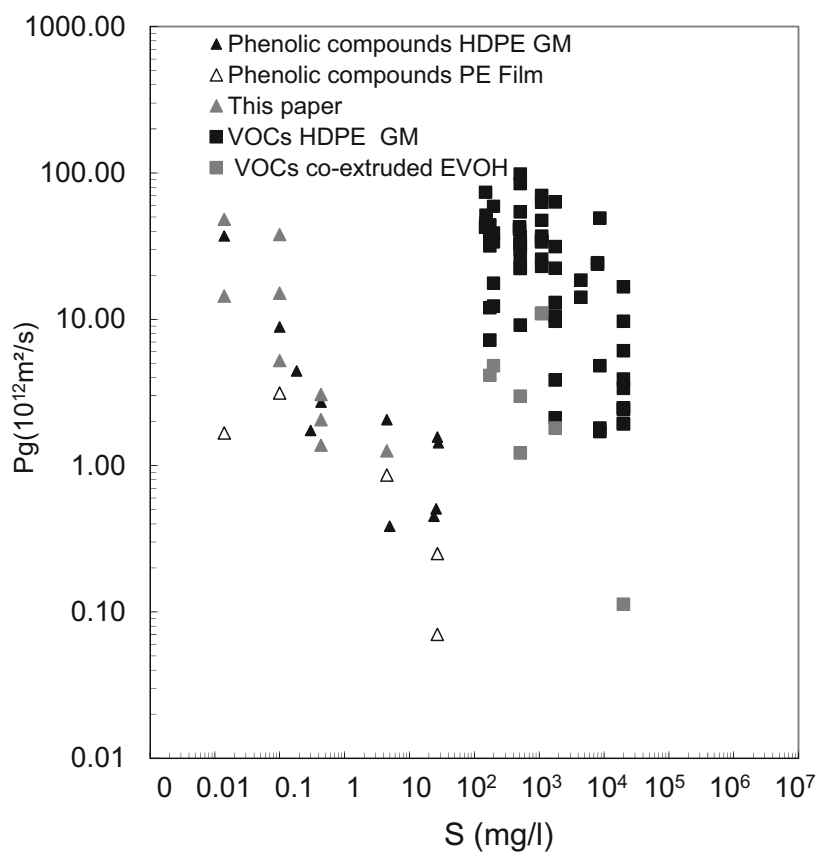

(b)

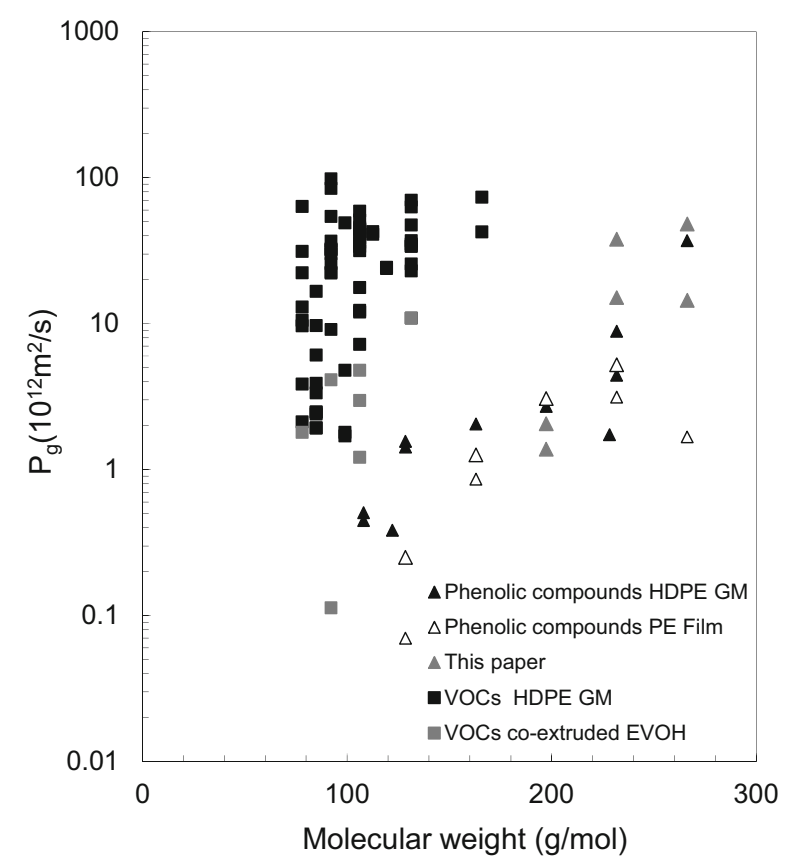

(d)

Fig. 6 Overview of permeation coefficients for the diffusion of VOCs and phenolic compounds in HDPE and coextruded geomembranes

These results thus differ from those previously obtained for the diffusion of VOCs in coextruded geomembranes and HDPE geomembranes. In fact, smaller permeation coefficients were obtained with coextruded geomembranes than with HDPE geomembranes. Nevertheless, the results of this study of the diffusion of phenolic compounds in a coextruded HDPE geomembrane tested indicate that the two coextruded HDPE geomembranes perform similarly to a HDPE geomembrane with respect to the diffusion of 2,4,6 TCP, 2,3,5,6 TECP, and PCP. 


\section{References}

1. Sisinno LS, Oliveira-Filho EC, Dufrayer MC, Moreira JC, Paumgartten JR (2000) Toxicity evaluation of a municipal dump leachate using zebrafish acute tests. Bull Environ Contam Toxicol 64(1):107-113

2. Takigami H, Matsui S, Matsuda T, Shimizu Y (2002) The Bacillus subtilis rec-assay: a powerful tool for the detection of genotoxic substances in the water environment. Prospect for assessing potential impact of pollutants from stabilized wastes. Waste Manag 22(2):209-213

3. Oman C, Hynning PA (1993) Identification of organic compounds in municipal landfill leachates. Environ Pollut 80(3): 265-271

4. Ahel M, Tepic N (2000) Distribution of polycyclic aromatic hydrocarbons in a Municipal solid waste landfill and underlying soil. Bull Environ Contam Toxicol 65(2):236-243

5. Robinson HD, Knox K, Van Santen A, Tempany PR (2001) Compliance of UK landfills with EU pollution emissions legislation: Development of a reporting protocol. In: Proceedings of Sardinia 2001, eighth international waste management and landfill symposium, Cagliari, 1-5 Oct 2001, pp 21-30

6. Hiroshi A, Toshihiko M, Nobutoshi T (2002) Endocrine disrupters in leachate from two MSW landfills of different waste compositions in Japan. In: Proceedings of the 2nd Asian Pacific landfill symposium, Seoul 2002, pp 728-736

7. Harmsen J (1981) Identification of organic compounds in leachate from a waste tip. Water Res 17(6):699-705

8. Bauer MJ, Herrmann R (1997) Estimation of the environmental contamination by phtalic acid esters leaching from household wastes. Sci Total Environ 208(1-2):49-57

9. Staples CA, Dorn PB, Kleska GM, O'Block S, Harris LR (1998) A review of the environmental, effects and exposures of bisphenol A. Chemosphere 36(10):2149-2173

10. Gron C, Christensen JB, Jensen D, Kjeldsen P, Ostfeldt P (1999) Organic halogens in landfill leachates. Water Air Soil Pollut 120(3-4):331-345

11. Christensen TH, Kjeldsen P, Bjerg PL, Jensen DL, Christensen JB, Baun A, Albrechtsen H, Heron G (2001) Biogeochemistry of landfill leachate plumes. Appl Geochem 16(7-8):659-718

12. Cousins IT, Staples CA, Klecka GM, Mackay D (2002) A multimedia assessment of the environmental fate of bisphenol A. Hum Ecol Risk Assess 8(5):1107-1135

13. Kjeldsen P, Barlaz MA, Rooker AP, Baun A, Ledin A, Christensen TH (2002) Present and long-term composition of MSW landfill leachate: a review. Crit Rev Environ Sci Technol 32(4):297-336

14. Niederer C, Goss K (2008) Effect of ortho-chlorine substitution on the partition behavior of chlorophenols. Chemosphere 71(4):697-702

15. Van Praagh M, Torneman N, Johansson M, Ingelstedt Frendberg LE, Heander E, Johansson A (2011) Emerging organic contaminants in leachate-review and risk assessment. In: Proceedings of Sardinia 2011, thirteenth international waste management and landfill symposium S. Margherita di Pula, 3-7 Oct 2011, CISA Publisher, Cagliari

16. Ramamoorthy S, Ramamoorthy S (1997) Chlorinated Organic Compounds in the Environment. CRC Press, Boca Raton

17. Kujawski W, Waszawski A, Ratajczak W, Porebski T, Capala W, Ostrowska I (2004) Removal of phenol from wastewater by different separation techniques. Desalination 163(1-3):287-296

18. Otero M, Zabkova M, Rodriguez AL (2005) Adsorptive purification of phenol wastewaters: experimental basis and operation of a parametric pumping unit. Chem Eng J 110(1-3):101-111
19. Rowe RK, Hrapovic L, Kosaric N (1995) Diffusion of chloride through an HDPE geomembrane. Geosynth Int 2(3):507-536

20. Park JK, Nibras M (1993) Mass flux of organic chemicals through polyethylene geomembranes. Water Environ Res 65:227-237

21. Prasad TV, Brown KW, Thomas JC (1994) Diffusion coefficients of organics in high density polyethylene (HDPE). Waste Manag Res 12:61-71

22. Müller W, Jakob R, Tatsky-Gerth, August H (1998) Solubilities, diffusion and partitioning coefficients of organic pollutants in HDPE geomembranes: experimental results and calculations. In: Proceedings of the 6th ICG, Atlanta, IFAI, vol 1, pp 239-248

23. Sangam HP, Rowe RK (2001) Migration of dilute aqueous organic pollutants through HDPE geomembranes. Geotext Geomembr 19(6):329-357

24. Park M, Benson CH, Edil TB (2012) Comparison of batch and double compartment test for measuring volatile organic compound transport parameters in geomembranes. Geotext Geomembr 31:15-30

25. McWaters RS, Rowe RK (2010) Diffusive transport of VOCs through LLDPE and two coextruded geomembranes. J Geotech Geoenviron Eng 136(9):1167-1177

26. McWaters RS, Rowe RK (2009) Transport of volatile organic compounds through PVC and LLDPE geomembranes from both aqueous and vapour phases. Geosynth Int 16(6):468-481

27. Eun J, Tinjum J, Benson CH, Edil TB (2014) Volatile organic coumpound (VOC) transport through a composite liner with coextruded geomembrane containing ethylene vinyl-alcohol (EVOH). In: Proceedings geo-congress 2014, ASCE, Atlanta, 1960-1969

28. Sangam HP, Rowe RK (2005) Effect of surface fluorination on diffusion through a high density geomembrane. J Geotech Geoenviron Eng 131(6):694-704

29. Rowe RK, Sangam HP, Lake CB (2003) Evaluation of an HDPE geomembrane after 14 years as a leachate lagoon liner. Can Geotech J 40(3):536-550

30. Islam MZ, Rowe RK (2008) Effect of geomembrane ageing on the diffusion of VOCs through HDPE geomembranes. In: Proceedings of the first pan American geosynthetics conference \& exhibition, Cancun (CD-ROM), pp 459-467

31. Islam MZ, Rowe RK (2009) Permeation of BTEX through unaged and aged HDPE geomembranes. J Geotech Geoenviron Eng 135(8):1130-1140

32. Touze-Foltz N, Ahari M, Mendes M, Barral C, Gardoni M, Mazéas L (2012) Diffusion of phenolic compounds through an HDPE geomembrane. Geotech Eng J SEAGS AGSSEA 43(4):19-29

33. Mendes MJA, Touze-Foltz N, Gardoni M, Guenne A, Mazeas L (2014) Diffusion of phenolic compounds through polyethylene films. Geosynth Int 21(2):137-150

34. Zhang Z, Britt IJ, Tung MA (1999) Water absorption in EVOH films and its influence on glass transition temperature. J Polym Sci B 37:691-699

35. Reinhard M, Goodman NL (1984) Occurrence and distribution of organic chemicals in two landfill leachate plumes. Environ Sci Technol 18(12):953-961

36. Sawhney BL, Kozloski RP (1984) Organic pollutants in leachates from landfill sites. J Environ Qual 13(3):349-352

37. Schrab GE, Brown KW, Donnelly KC (1993) Acute and genetic toxicity of municipal landfill leachate. Water Air Soil Pollut 69(1-2):99-112

38. Nininen M, Kalliokoski P (1994) Effect of organic contaminants in landfill leachates on groundwater quality in Finland. Groundwater Quality Management (Proceedings of the GQM 93 Conference held at Tallinn, Sept 1993). IAHS Publ. No. 220, pp 64-71 
39. Yasuhara A, Shiraishi H, Nakasugi O, Yamamoto T, Nishikawa M, Okumura T, Kenmotsu K, Fukui H, Nagase M, Kawagoshi Y (1999) Organic components in leachates from hazardous waste disposal sites. Waste Manag Res 17(3):186-197

40. Lee M, Yeh Y, Hsiang W, Hwang B (1998) Solid-phase microextraction and gas chromatography mass spectrometry for determining chlorophenols from landfill leaches and soil. J Chromatogr A 806(2):317-324

41. Viraraghavan T, Alfaro FM (1998) Adsorption of phenol from wastewater by peat, fly ash and bentonite. J Hazard Mater 57(1-3):59-70

42. Yamada K, Urase T, Matsuo T, Suzuki N (1999) Constituents of Organic Pollutants in Leachates from different types of landfill sites and their fate in the treatment processes. J Jpn Soc Water Environ 22(1):40-45

43. Banat F, Al-Bashir B, Al-Asheh S, Hayajneh O (2000) Adsorption of phenol by bentonite. Environ Pollut 107(3):391-398

44. Paxeus N (2000) Organic compounds in municipal landfill leachates. Water Sci Technol 42(7-8):323-333

45. Behnisch PA, Fujii K, Shiozaki K, Kawakami I, Sakai S (2001) Estrogenic and dioxin-like potency in each step of a controlled landfill leachate treatment plant in Japan. Chemosphere 43(4-7):977-984

46. Yamamoto T, Yasuhara A, Shiraishi H, Nakasugi O (2001) Bisphenol $\mathrm{A}$ in hazardous waste landfill leachates. Chemosphere 42(4):415-418

47. Koumanova B, Peeva-Antova P (2002) Adsorption of p-chlorophenol from aqueous solutions on bentonite and perlite. J Hazard Mater 90(3):229-234

48. Ribeiro A, Neves MH, Almeida MF, Alves A, Santos L (2002) Direct determination of chlorophenols in landfill leachates by solid-phase micro-extraction-gas chromatography-mass spectrometry. J Chromatogr A 975(2):267-274

49. Reitzel LA, Lundin A (2002) Determination of phenols in landfill leachate-contaminated groundwaters by solid-phase extraction. J Chromatogr A 972(2):175-182

50. Schwarzbauer J, Heim S, Brinker S, Littke R (2002) Occurrence and alteration of organic contaminants in seepage and leakage water from a waste deposit landfill. Water Res 36(9):2275-2287

51. Baun A, Ledin A, Reitzel LA, Bjerg PL, Christensen TH (2004) Xenobiotic organic compounds in leachates from ten Danish MSW landfills - chemical analysis and toxicity tests. Water Res 38(8):3845-3858
52. Nagasaki S, Nakagawa Y, Tanaka S (2004) Sorption of nonylphenol on Na-Montmorillonite. Colloids Surf A 230(1-3): 131-139

53. Yu J, Shin M, Noh J, Seo J (2004) Adsorption of phenol and chlorophenols on Ca-montmorillonite in aqueous solutions. Geosci J 8(2):185

54. Ozkaya B (2005) Chlorophenols in leachates originating from different landfills and aerobic composting plants. J Hazard Mater 124(1-3):107-112

55. Slack RJ, Gronow JR, Voulvoulis N (2005) Household hazardous waste in municipal landfills: contaminants in leachate. Sci Total Environ 337(1-3):119-137

56. Richards S, Bouazza A (2007) Phenol adsorption in organomodified basaltic clay and bentonite. Appl Clay Sci 37:133-142

57. Limam I, Guenne A, Driss M, Mazeas L (2010) Simultaneous determination of phenol, methylphenols, chlorophenols and bisphenol-A by headspace solid-phase microextraction-gas chromatography-mass spectrometry in water samples and industrial effluents. Int J Environ Anal Chem 90(3-6):230-244

58. Nefso EK, Burns SE (2007) Comparison of the equilibrium sorption of five organic compounds to HDPE, PP, and PVC geomembranes. Geotext Geomembr 25:360-365

59. Touze-Foltz N, Rosin-Paumier S, Mazéas L, Guenne A (2011). Diffusion of volatile organic compounds through an HDPE geomembrane. In: Proceedings of the geofrontiers, IFAI, pp 1121-1130

60. Rowe RK, Booker, JR (1997) POLLUTE v. 6.3: 1D pollutant migration through a non-homogeneous soil. Distributed by GAEA Environmental Engineering Ltd., Whitby

61. Rowe RK (1998) Geosynthetics and the minimization of of contaminant migration through barrier systems beneath solid waste. In: Proceedings of the 6th international conference on geosynthetics, Atlanta, IFAI, vol 1, pp 27-103

62. Joo JC, Kim JY, Nam K (2004) Mass transfer of organic compounds in dilute aqueous solutions into high density polyethylene Geomembranes. J Environ Eng 130(2):175-183

63. Joo JC, Nam K, Kim JY (2005) Estimation of mass transport parameters of organic compounds through high density polyethylene geomembranes using a modifield double-compartment apparatus. J Environ Eng 131(5):790-799 